America, 1979-1989. Western Birds 22:145-155.

23. Springer, A. M., A. Y. Kondratyev, H. Ogi, Y. V. Shibaev, and G. B. van Vliet. 1993. Status, ecology, and conservation of Synthliboramphus murrelets and auklets. In: Vermeer, K., Briggs, K. T., Morgan, K. H. and Seigel-Causey, D. (eds.). The Status, Ecology, and Conservation of Marine Birds of the North Pacific. Canadian Wildlife Service Special Publication, Ottawa. Pp. 187201.
24. Verbeek, N. A. M. 1966. Wanderings of the Ancient Murrelet: some additional comments. Condor 68:510-511.

25. Waldon, J. 1994. Ancient Murrelet in Devon: new to the Western Palearctic. British Birds 87:307-310.

26. Weseloh, D. V., and L. K. Weseloh. 1978. First record of the Ancient Murrelet for Alberta. Canadian Field-Naturalist 92:200-201.

27. Wisely, A. M. 1983. Ancient Murrelet in Calgary. Alberta Naturalist 13:49-50.

\title{
POWER POLES ASSIST RANGE EXPANSION OF OSPREYS IN SASKATCHEWAN
}

C. STUART HOUSTON, 863 University Drive, Saskatoon, SK S7N 0J8, and FRANK SCOTT, Box 2, GS 317, Saskatoon, SK S7K 3J6

In eastern North America, Ospreys have built nests on man-made platforms, towers, and duck-hunting blinds since at least $1881 .{ }^{3}$ Use of power utility structures is much more recent. ${ }^{5}$ In southern Ontario, wooden double cross-arm poles appeared as early as 1915; there was then a 57-year lag before Ospreys built nests on such poles in the Georgian Bay region, starting with one nest on a pole in 1972 and increasing to nests on 12 poles in $1989 .{ }^{2}$ By 1980 every Canadian province except Quebec and Saskatchewan had recorded such events. ${ }^{1,3}$ In Oregon, there was a 20-year lag between building of power poles for electric irrigation pumps and their use by
Ospreys; use then increased by leaps and bounds, from 1 pole in 1977 to 66 in 1993. ${ }^{3}$

This paper describes the extension of Osprey breeding range south from boreal forest lakes, their common habitat across most of Canada, into aspen parkland in Saskatchewan. In the late 1980s, Ospreys began to build nests on power poles near Murray and Jackfish lakes, and in 1998 nests were built at two places where power lines crossed the South Saskatchewan river. Power line poles appear to have facilitated both these range extensions and have led to local increases in the Osprey population. 
1. High-voltage transmission line east of Murray and Jackfish lakes:

In the late 1980s, local farmers reported that the first Osprey pair nested on top of a power pole along the 138 KV Saskatchewan Power Corporation (SPC) Brada-Glaslyn power line, installed in 1975. By 2000, there were 15 nests built by Ospreys along a 20 $\mathrm{km}$ section of transmission line, though one was taken over by a Red-tailed Hawk that year. Each nest had been built on top of one of the poles, 15 to $23 \mathrm{~m}$ above ground and about $1.3 \mathrm{~m}$ to the inside of one of two active transmission lines (Fig. 1). Except for the most northerly nest, each had a view of either Murray or Jackfish Lake.

In 1999, an aerial check by Frank Scott showed that only two pairs had raised young to fledging. On July 8, SPC Patrolman Ken McComas climbed to both nests and passed down three young from each for Stuart Houston (CSH) to band. Earlier, there had been young in at least some of the other nests; we suspect that starvation or predation by a Great Horned Owl may have caused their demise.

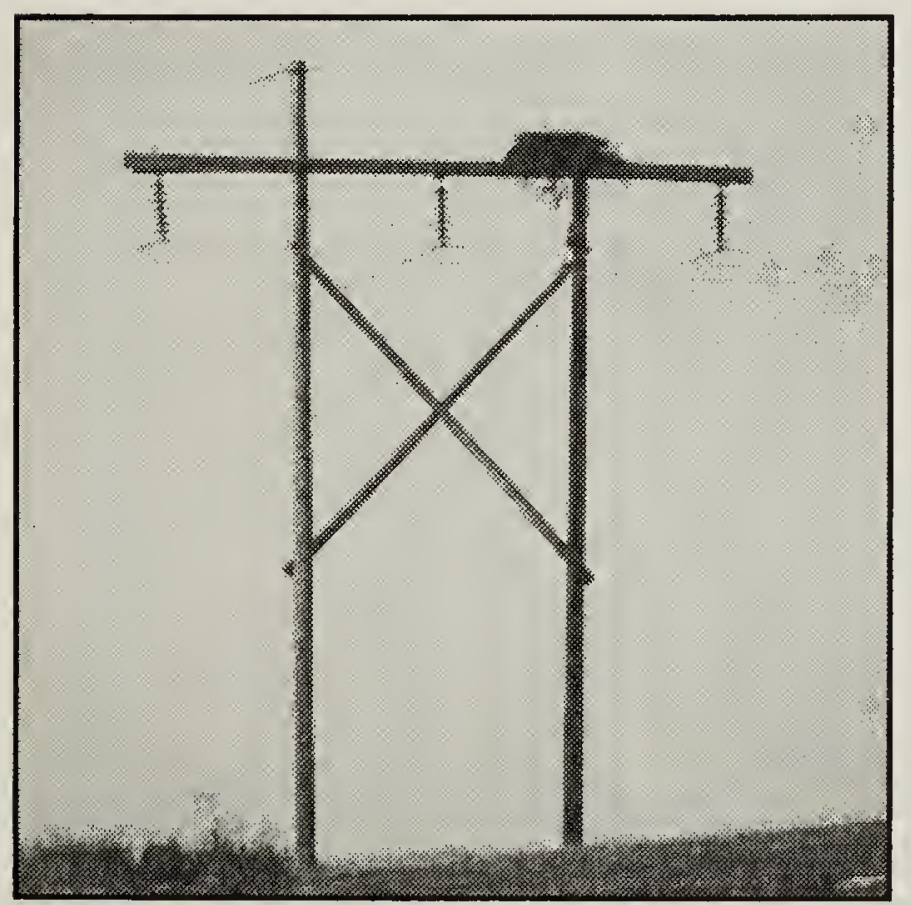

Figure 1. Osprey nest on shortest pair of poles on SPC Brada-Glaslyn power line.

Marten J. Stoffel
In the year 2000, a check from the ground by Ken McComas on May 29 and from the air by Frank Scott on 11 July, revealed that adult Ospreys were present at 12 nests. The southernmost nests were closest to Murray Lake, one nest being only $1 \mathrm{~km}$ distant. The most northerly nest was a surprising $10.2 \mathrm{~km}$ from Jackfish Lake, and produced only one young. On July 20 , each pole with an active nest was nimbly climbed, using spurs and full safety equipment, by Ken McComas who passed the young down to $\mathrm{CSH}$ to band. Three nests had 3 young each, two had 2 and two had 1. Young could not be reached in the eighth successful nest, which was five feet deep and probably the first nest built on this line, in the late1980s. One nest with young apparent on July 11 and another with presence of young uncertain when viewed from an airplane, were empty when climbed on July 20, and two other nests with adults present had no visible young at any time.

In 2001, there were ten successful nests. Rain and poor roads prevented a visit to the northernmost nest and young in the deep nest remained unreachable. Ken McComas again climbed the poles and passed down the young; six of the climbed nests contained three young and two contained two, for a total of 22 young banded in 8 nests.

\section{High-voltage distribution lines crossing the South Saskatchewan river:}

The first known Osprey nests along the South Saskatchewan River were seen in 1998 on local $25 \mathrm{KV}$ power lines, one on the east side of the river east of Rosthern, and the other, about $20 \mathrm{~km}$ to the southwest, on the west side of the river east of Hague. Each nest was small, suggesting that it had been used only once. 
Unlike the situation on the highvoltage line, both nests were built right on top of live wires; baler twine dangling from one smouldered but did not break into full flame. Since the need to move the nests off the power line was evident, we proposed to SPC that they install a new pole on which we could build a nest platform, about $50 \mathrm{~m}$ from the transmission line. On 9 October 1998, Keith Reeder and Ken Morash of SPC planted a $12 \mathrm{~m}$ pole $2 \mathrm{~m}$ into the ground, immediately west of where the power line crossed the river east of Hague. Martin Gerard built a platform on the new pole, to which Marten Stoffel helped him add'the sticks from the former nest, knocked from the powerline the week before (Fig. 2). On 2 February 1999, the nest east of Rosthern was moved onto its new platform (Fig. 3).

Both nests on the new platforms were occupied by Ospreys in April 1999, but the pair east of Hague failed to raise young that year. The pair near Rosthern reared two young which were banded on July 16 by Martin Gerard (Fig. 4). In 2000, the Ospreys returned (Fig. 5) and each of the nests on the riverbank poles produced three young. In 2001, the

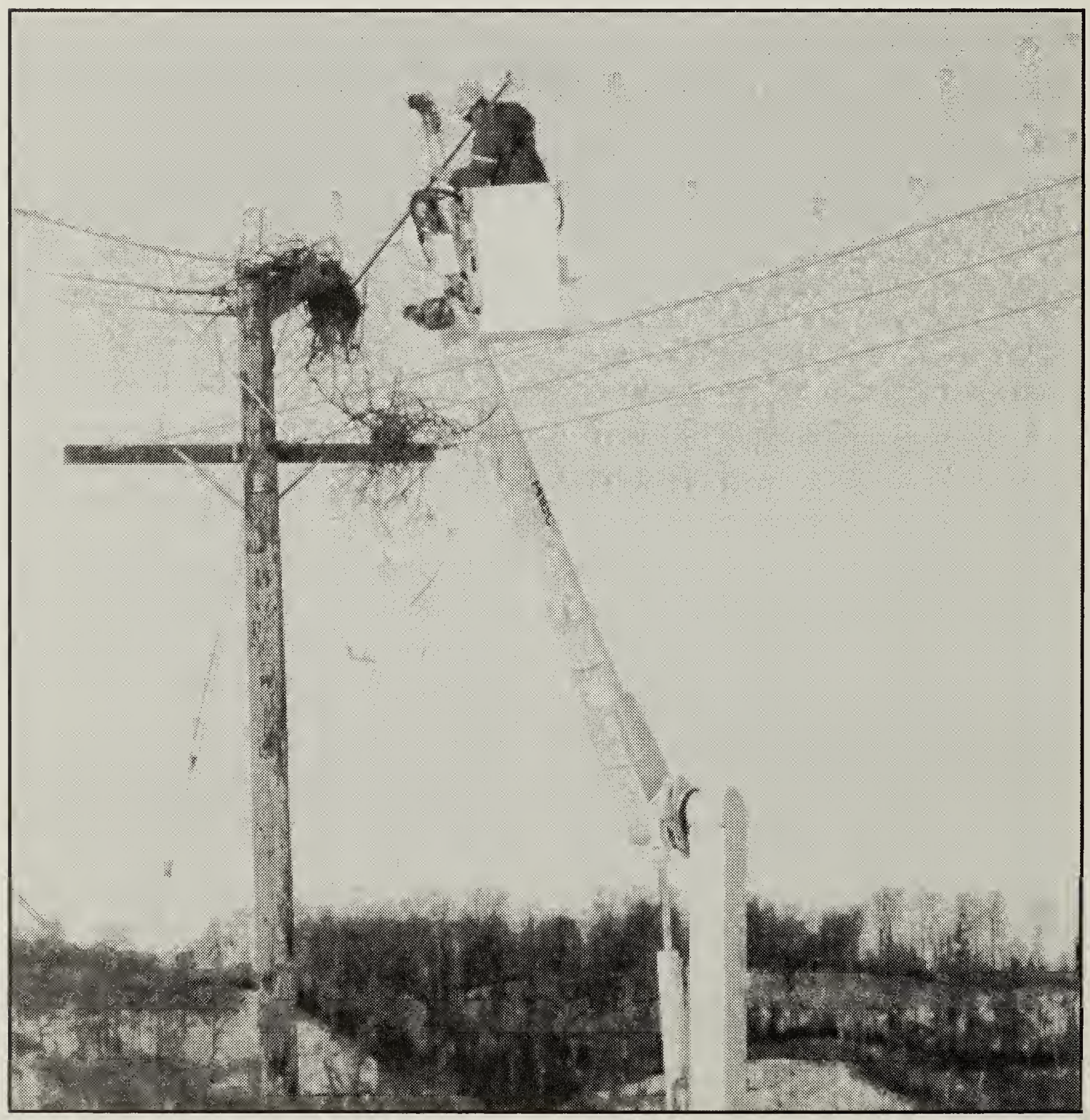

Figure 2. Keith Reeder knocking down 1998 Osprey nest east of Hague. Richard Marjan. Courtesy The StarPhoenix 
Hague nest produced one young and the Rosthern nest two.

The recent range extension of ospreys into the boreal forest - parkland fringe is not confined to power line poles. Osprey nesting activity began at Turtle Lake in west-central Saskatchewan and in the Preeceville area in east-central Saskatchewan. ${ }^{4}$ Muriel Carlson (pers. comm.) recorded her first Osprey nest at the north end of Turtle Lake in 1985 and Paul Chartrand (pers. comm.) knew of one nesting pair a few years earlier. During a boat trip around the north half of the lake on June 20,2000, Muriel Carlson observed at least ten Osprey adults. On 22 July, aided by Kevin and Judy Wilkinson, Muriel took us to three active nests where Paul Gully climbed and banded eight young.

\section{Spin-offs:}

1. An increased number of Ospreys has been banded in the last three years. SPC poles provided an additional 8

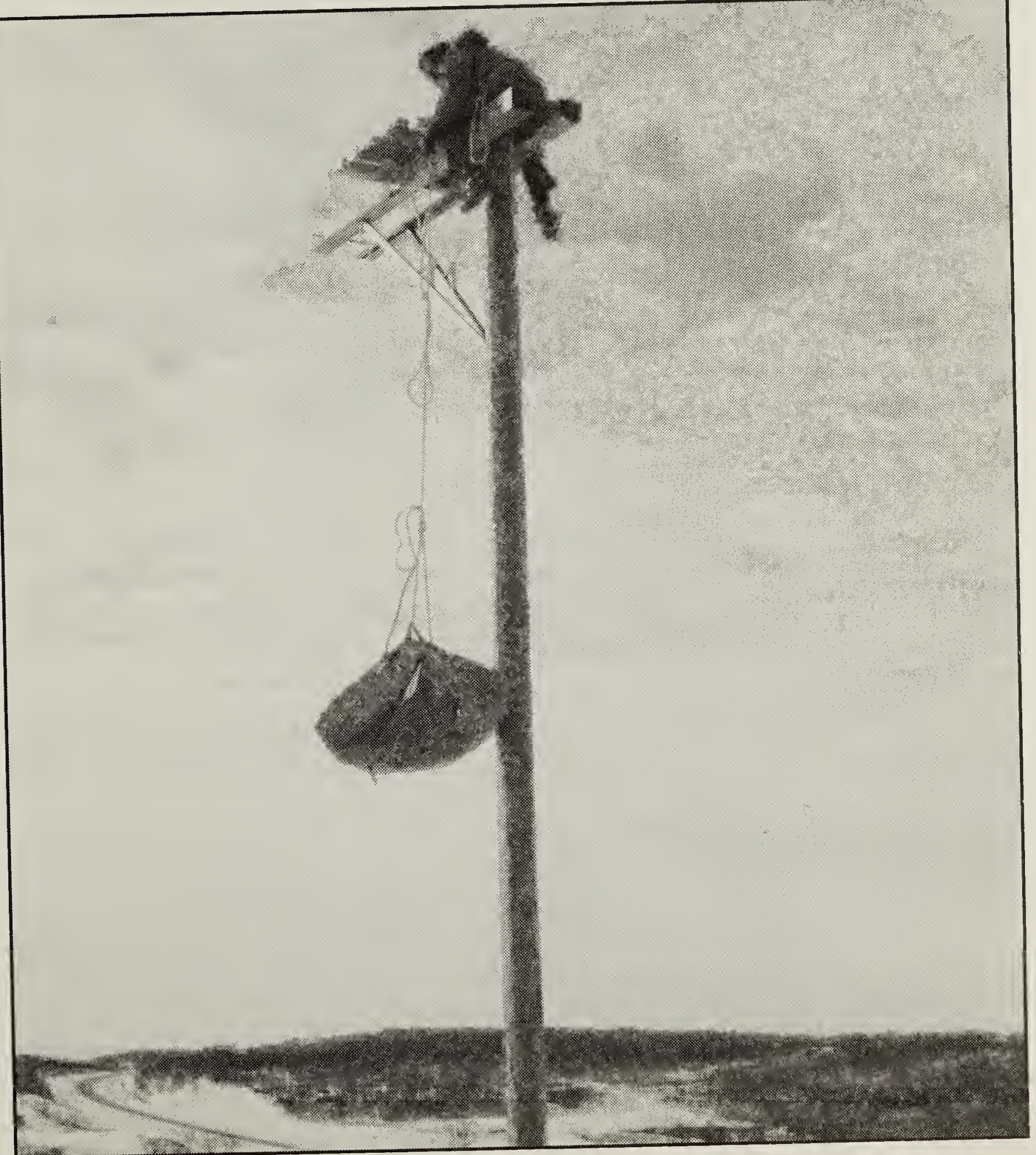

Figure 3. David Miller raising nest contents to platform east of Rosthern.

Richard Marjan. Courtesy The StarPhoenix 


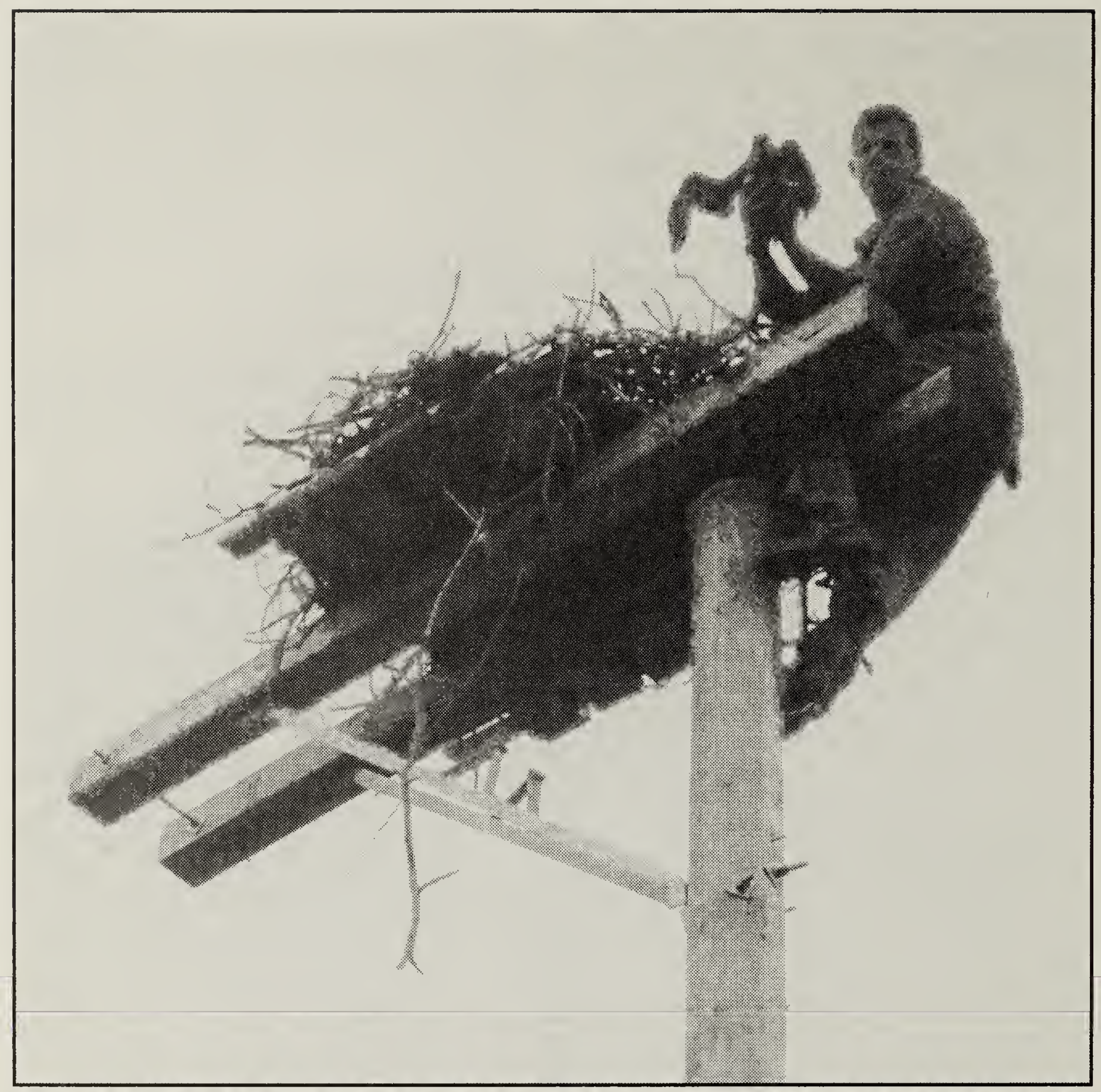

Figure 4. Martin Gerard banding young Ospreys on platform east of Rosthern, 16 July 1999. Kim McNairn. Courtesy The StarPhoenix

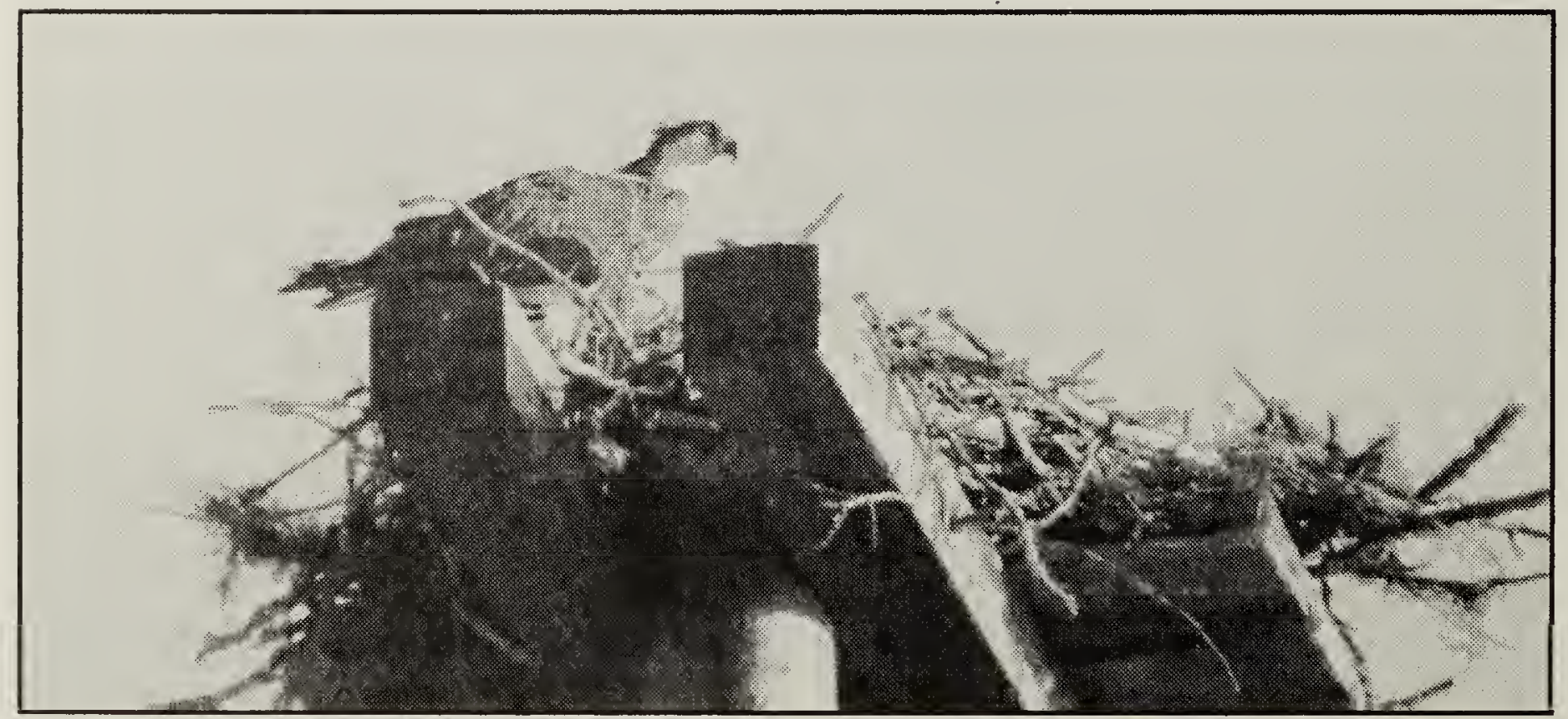

Figure 5. Osprey on platform east of Rosthern, June 2000.

Brenton Terry 
Figure 6. Numbers of Ospreys banded each year in Saskatchewan by C.S. Houston, 1975 - 2001

\section{Ospreys banded in Saskatchewan by C. S. Houston, 1965-2001 $(n=535)$}

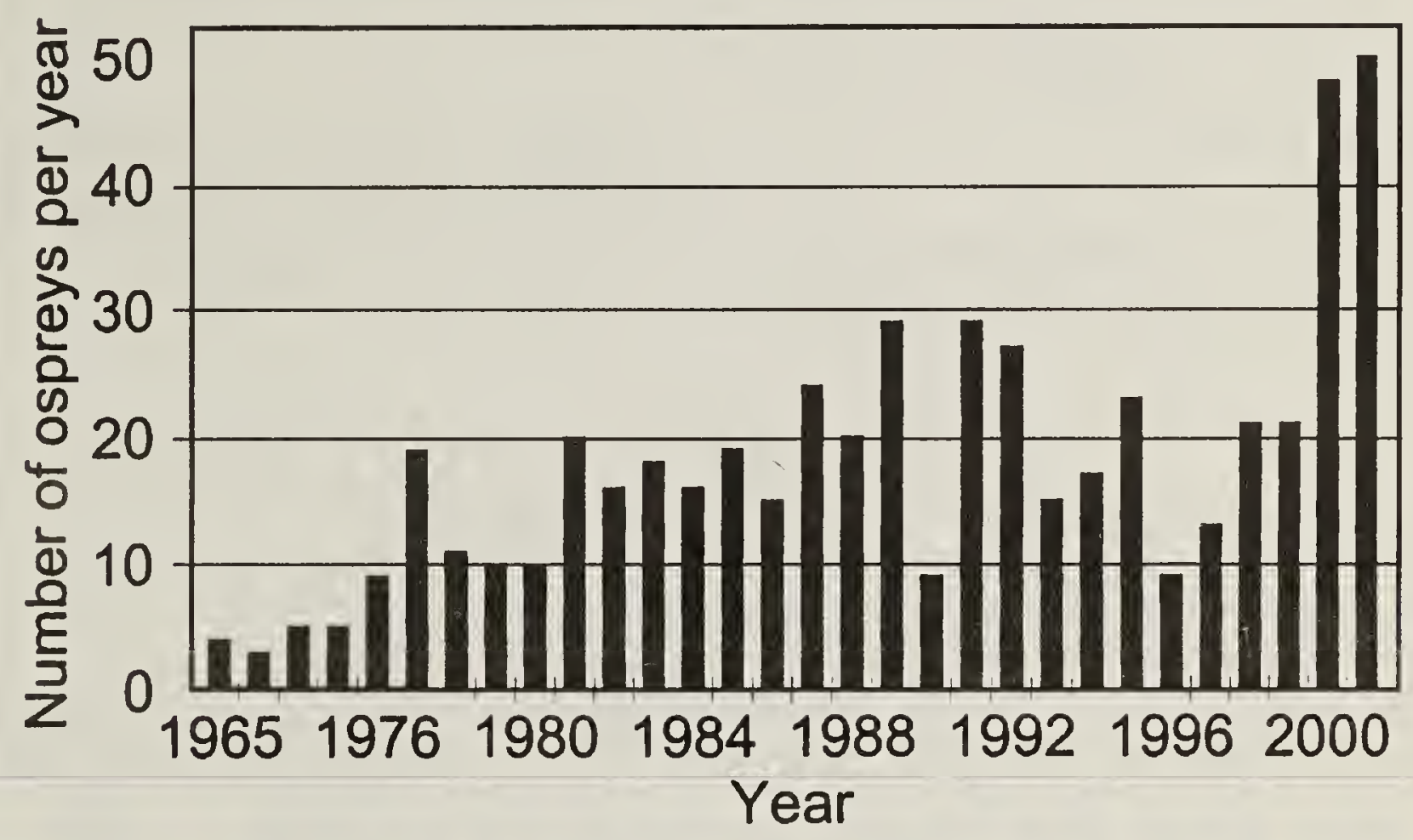

nestlings in 1999, 21 nestlings in 2000 , and 25 nestlings in 2001. A record 48 nestlings were banded in 2000 and 50 in 2001 (Fig. 6), the latter including three new sites in trees at Turtle Lake.

2. More important, building the nest platforms with SPC help was a win-win situation for the company, for banders and for Ospreys. Near Hague and Rosthern, SPC has greatly reduced the risk of fire and consequent power outage, and nestling Ospreys are no longer at risk from fire and electrocution. Banders have much safer present and future climbing.

\section{Acknowledgments:}

We wish to thank Larry Christie and Bernie Bolens of Saskatchewan Power Corporation (SPC), Regina, for their support. Keith Reeder of the SPC Rosthern office provided the "cherrypicker" and manpower to install the new poles. Ken McComas of the SPC Saskatoon office checked nests along the Brada-Glaslyn power line from the ground on 29 May 2000. Although climbing with spurs is no longer a part of his regular duty, Ken cheerfully spent nearly half a day climbing poles in 1999 , and a full day each in 2000 and 2001. Marten Stoffel located the Hague and Rosthern nests on powerlines in 1998. Muriel Carlson and Kevin and Judy Wilkinson located nests near Turtle Lake. Martin Gerard and David Miller rebuilt the nests on the Hague and Rosthern platforms, respectively. Richard Marjan and Kim McNairn of the Saskatoon StarPhoenix, Marten J. Stoffel and Brenton Terry provided photographs. Richard Harkness helped locate early references relating to power line usage elsewhere.

1. Austin-Smith, P.J., and G. Rhodenizer. 1983. Ospreys relocate 